Anquan Feng

\title{
The shale revolution and Sino-Russian energy cooperation
}

\begin{abstract}
With the progress of technology, the production cost of shale oil and gas will decrease again, and, in turn, the competitive advantage of shale oil and gas over conventional oil and gas exploitation will be enhanced. Obviously, this will lead to changes in the international oil and gas energy pattern. The paper discusses the impact of the shale revolution on the international energy market, and analyses the trends in Sino-Russian energy cooperation. Methodologically, the paper relies on a center of gravity theory as applied to oil and gas production and consumption. The main research method is comparative analysis of energy exports and imports between China and Russia under the development of technologies for shale oil and gas production. The impact of the shale revolution on China is increased number of channels of oil and gas import, increased exploitation of oil and gas resources, reduction in China's energy imports, and the country's stronger voice in the energy market. The impact on Russia is added competitive pressure in the energy market, and increased stimulus to exploitation of unconventional energy in Russia. The paper outlines prospects for Sino-Russian cooperation in oil and gas export and import given the emerging structure of the market, and lists obstacles in the way to successful cooperation between the countries.
\end{abstract}

Keywords: shale revolution; Russia; China; petroleum; natural gas; energy cooperation.

For citation: Feng A. Q. The shale revolution and Sino-Russian energy cooperation. Journal of New Economy, 2019, vol. 20, no. 4, pp. 108-118. DOI: 10.29141/2073-1019-2019-20-4-6

Received April 29, 2019.

\section{Introduction}

A $s$ the most important fossil fuel for the current industrial production and social develop-

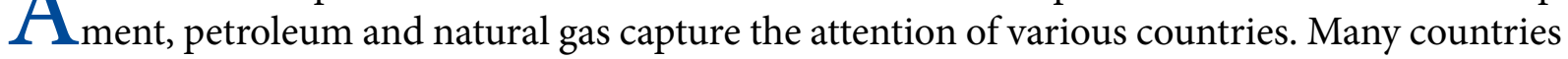
regard the supply of petroleum and natural gas energy as the essential component of national security. Some energy exporting countries utilize the petroleum and natural gas to obtain a benefit in the international relations. The supply of and demand for oil and gas energy has become an important issue in the competition among the great powers.

At present, the exploitation of shale oil and gas energy has developed into a significant factor affecting the world oil and gas energy production and the marketing pattern while the international conventional oil and gas resources exploitation areas are dominated by the world's oil giants. In recent years, the United States, which has always been known as a major importer and consumer of oil and gas, has started a large-scale shale oil and gas exploitation, which made the country an exporter of oil and gas. Although there are three countries, including the United States, Canada and China, now engaged in the commercial shale gas exploitation, the amount of shale gas produced in Canada and China is rather small to affect the pattern of the international natural gas market. Of them, only the United States is carrying out a large-scale commercial exploitation. Nonetheless, the shale revolution exerted a profound impact on the world energy supply. In the long term, with the popularization and improvement of the mining technologies, the shale revolution is going to have a greater and greater impact on the international oil and gas energy production and the marketing pattern. 
The purpose of the paper is to study the Sino-Russian oil and gas energy cooperation against the background of the shale revolution. The main tasks of the paper are to diagnose the basic situation with the shale revolution in the world today, examine its influence on the international energy pattern and the new situation of energy cooperation between China and Russia, and finally, to put forward suggestions for strengthening energy cooperation between the two countries.

\section{Basic condition of the shale revolution}

The shale revolution is sponsored and led by America in order to mine the unconventional oil and gas resources. After decades of exploration, America has achieved a breakthrough in the mining of shale oil and gas. In the past ten years, the output of shale gas has multiplied. Led by America, the scope of countries mining shale gas has expanded to Canada and China. However, in terms of the mining technology and scales, other countries could not fight with America for the leadership in the shale revolution.

At present, the technology for a large-scale commercial mining of shale oil is mainly mastered by America's oil enterprises. The United States have seriously decreased its import dependency on petroleum by mining shale oil. Although many countries regard the mining of shale oil as the important goal of local energy development, none of them, except for America, has achieved the scales of commercial development. The overall condition of storage and exploitation of shale oil and gas influenced the development of the international energy context. In the future, as the great powers possessing the shale resources master the necessary technologies, the shale revolution is going to create even larger impact on the international energy context.

The shale gas reserves in the world are mainly located in North America, Latin America, Central Asia, China, South Africa and the Middle East, where there are about 95 shale gas basins and 137 shale strata. The geological resources with risk are about 1,013 trillion $\mathrm{m}^{3}$, and the technically recoverable resources are about 220 trillion $\mathrm{m}^{3}$ [Men, Han, Wang, 2018]. The top ten countries by the amount of technically recoverable shale oil resources are presented in the Table.

Top ten countries by technically recoverable shale oil resources

Рейтинг стран по объему технически извлекаемых ресурсов сланцевой нефти

\begin{tabular}{|c|c|c|}
\hline Rank & Country & Technologically recoverable reserves (billion tonnes) \\
\hline 1 & Russia & 75 \\
\hline 2 & USA & 58 \\
\hline 3 & China & 32 \\
\hline 4 & Argentina & 27 \\
\hline 5 & Libya & 26 \\
\hline 6 & Venezuela & 13 \\
\hline 7 & Mexico & 9 \\
\hline 8 & Pakistan & 9 \\
\hline 9 & Canada & 8 \\
\hline 10 & Indonesia & \\
\hline
\end{tabular}

Source. US Energy Information Administration. Technically recoverable shale oil and shale gas resources: An assessment of 137 shale formations in 41 countries outside the United States. Available at: https://www.eia.gov/analysis/studies/worldshalegas/pdf/overview.pdf

America is both the leading country of the shale revolution and the largest beneficiary country. At present, America achieves self-sufficiency with oil and gas energy by mining the shale oil and gas. Just because America's shale oil and gas output sharply increases, the international energy situation changes. After the shale revolution, the United States overtook Saudi Arabia as 
the world's largest oil producer and boosted oil exports. Undoubtedly, this will challenge materially the traditional game rules and pricing models of the international oil market and exert a profound influence on the construction of the new oil order [O'Sullivan, 2017].

In 2009, America's natural gas output reached 624 billion $\mathrm{m}^{3}$, which surpassed the output of Russia, and America became the largest natural gas producing country in the world. In 2010, America's shale gas output increased to 100 billion $\mathrm{m}^{3}$, and its proportion in America's natural gas output increased to $20 \%$ from $1 \%$ five years ago [Wang, 2018]. In 2016, the shale gas output approximated to 420 billion $\mathrm{m}^{3}$, accounting for about $53 \%$ of America's natural gas output [Wang, Jin, 2018]. In 2017, the total natural gas output in the USA reached 936.6 billion $\mathrm{m} 3$, of which the shale gas output was 462.1 billion $\mathrm{m}^{3}(49.4 \% \text { of the total })^{1}$. With the opening of the relevant policies in America, the output of shale gas is likely to continue soaring.

China is the third largest shale gas producing country after the United States and Canada. In the new century, China is attaching more importance to the mining of shale gas. In the recent decade, the country has launched many plants for mining shale gas. However, the commercial mining of shale gas has been achieved only recently, and the quantity produced is rather small. In 2015, China's shale gas output reached 4.47 billion $\mathrm{m}^{3}, 3$ times higher than in the previous year before. In 2016, the output increased by almost $75 \%$ and reached 7.82 billion $\mathrm{m}^{3}$, accounting for $5.76 \%$ of the total output of the natural gas. In 2017, the output reached 9.1 billion $\mathrm{m}^{3}$ ( $6.4 \%$ of the total). Although the output of shale gas increases constantly, it is much less than the national planned and anticipated output. The state of reserves and technological capabilities for mining shale gas in China allow concluding that it is difficult to achieve a huge growth of the shale gas quantity in the short term.

The exploration and development of shale oil in China is late, and the complicated geological environment makes it even more difficult. At present, the exploitation of shale oil in China is still in its infancy and has not yet entered the stage of industrial exploitation. By 2016, PetroChina has drilled 686 wells and put 651 wells into operation in the test areas of Changqing and Daqing, producing 795,000 tonnes of shale oil in that year with cumulative total of 2.52 million tonnes of shale oil. According to the 13th Five-Year Plan for China's Energy Development, shale oil production is expected to reach 1 million tonnes by 2020 and achieve commercial breakthroughs. Yet at present, attaining this goal seems problematic.

Russia is the country with the largest reserves of shale oil. However, its conventional oil and gas reserves are still larger, and mining shale oil needs lots of capital and high technologies, hence the country mines shale oil on a very small scale. In 2017, the shale oil output reached 20,000 barrel/day [Chen, Wu, 2018]. As America's mining technology of shale oil becomes increasingly mature and the mining costs decline, Russia is paying more attention to the exploration and mining of the shale oil. In order to improve the enterprises' impetus for mining the shale oil, Russian government provides the corresponding preferential tax policy for enterprises ${ }^{2}$.

Gazprom has focused on the research and development of the shale oil mining technology, and is planning to carry out commercial production in the next few years. If the shale oil production goes smoothly, Russia's total oil and gas production will increase significantly. Since 2014, the Russian government has implemented a tax-free policy for the exploration and development of shale oil. At present, Gazprom has started a small-scale production in Siberia. In

\footnotetext{
${ }^{1}$ Natural Gas Research Center of Oil Observation Think-Tank. (2018). Meiguo tianranqi chanlian zaihuo zengzhang [Regrowth of America's natural gas output]. Tianranqi zhoukan = Natural Gas Intelligence Collection, vol. 38, pp. 59-62. (in Chinese)

${ }^{2}$ Yeyanyou chuxian zhengrong rechaolaidong ladong xinyilun youjia shangzhang [The shale oil is beginning to emerge. The boom has driven a new round of international oil prices]. Available at: http://www.sohu. com/a/227061335_100097967 (in Chinese)
} 
addition, the Rosneft Oil and BP signed a cooperation agreement to explore shale oil jointly in the Volga-Ural region.

\section{The shale revolution impact}

The shale energy revolution occurs when conventional fossil energy resources are exhausted. By now, only America has been able to master the mining technology of shale energy well enough to conduct the large-scale business development of the shale energy. All other countries will inevitably focus on mining the shale energy reserves on the Earth when the sources of conventional fossil energy are depleted. The shale energy revolution will create a powerful impact on the world energy situation, models of joint mining, and energy consumption.

America is the most successful country in the mining of the shale energy. By doing this, the country does not only efface the reputation of being the largest oil and gas importer, it becomes the net exporter of natural gas by mining the shale gas. In addition, its petroleum import dependency decreases year by year. The energy consumption of America as the first big economic power in the world is staggering. In 1948, America became the net importer of petroleum, and in 1998 , its import dependency went up to $51.6 \%$, which surpassed a $50 \%$ international warning line for the first time. At the beginning of this century, America's petroleum import dependency kept on going up and amounted to $66.3 \%$ (a peak value) in 2005. With the output of the shale oil increased, the country's import dependency started to decline. In 2010 and 2011, the import dependency decreased to $57.2 \%$ and $52.6 \%$ respectively [Yin, Zhang, 2013]. At the end of 2015, President Obama signed the bill and lifted the 40-year ban on crude oil exports. In 2017, America exported 170 million tonnes of crude oil, the net import volume decreased greatly, and the petroleum import dependency went down to $33.2 \%$, which was the lowest level over the past 60 years ${ }^{1}$. With the rising oil prices and the development of the shale oil mining technology, America's shale oil output will undoubtedly improve, and its export will rapidly increase.

If the production of shale oil reduces America's petroleum import dependency, the development of shale gas allows America to become a natural gas export power. In 2016, America was a net importer of natural gas, with the net import volume of 685 billion $\mathrm{ft}^{3}$, while in 2017 America became a net exporter of natural gas ${ }^{2}$.

The sources of oil and gas import for the United States were once located in highly volatile regions such as the Middle East and Africa, which undoubtedly threatened the US energy security. Through the shale energy revolution, the United States not only reduced its dependency on oil to a secure level, but also became a net exporter of natural gas, and the country's energy security situation has significantly improved. Therefore, the shale energy revolution not just guarantees the energy security of the United States, but also enables the American people to enjoy low oil and gas prices, reduces the cost of living and production, and enhances the competitiveness of enterprises. At the same time, through the shale revolution, the international influence of the United States strengthened further, and the impact on the international energy pattern became even greater. For energy exporters such as Canada and Argentina, the shale energy revolution will undoubtedly increase their oil and gas sources, ensure their adequate energy exports and promote their economic development. Though possessing large reserves of shale oil and gas, China is still at the initial stage of shale oil and gas exploitation, but with the improvement of the mining technology, a huge amount of shale energy reserves will ease the energy shortage in China.

The improvement of the shale oil mining technology significantly reduced the cost of mining

1 Wang N. Q. Shiyou duiwai yicundu $70 \%$ kepama?[ Is $70 \%$ import dependence of petroleum horrible?]. Available at: https://baijiahao. baidu. com/s? id =1599549775556453471\&wfr = spider\&for = pc (in Chinese)

${ }^{2}$ U.S. Natural Gas Imports \& Exports 2016. Available at: https://www.eia.gov/naturalgas/importsexports/annual/ 
shale oil in America. In 2014, the cost of mining equaled 60-70 US dollars per barrel, while in 2017, the cost decreased to less than 20 US dollars per barrel, which enhanced the international competitiveness of America's export petroleum, and will inevitably make the country race to control and increase its share in the international energy market.

In 2017, China's import of crude oil went up to 420 million tonnes, and China became the largest importer of crude oil in the world. Before 2017, China imported crude oil mainly from the Middle East, Africa, Russia, Central Asia and Venezuela, and China almost did not buy petroleum from the USA. In 2017, China imported 6.76 million tonnes of crude oil from America, which accounted for $1.6 \%$ of China's total crude oil imports. In the first quarter of 2018, China's crude oil imports from the United States rose sharply, accounting for $2.5 \%$ of China's oil imports in the same period ${ }^{1}$. With the increase of America's crude oil exports, China will import more crude oil from America in the future. The shale energy revolution will expand the energy import channels for China by diversifying energy import sources.

The shale energy revolution influences both importers and exporters of energy. Russia is the energy export power, and its economy severely depends on the petroleum and natural gas exports. In 2017, Russia's exports reached 357 billion US dollars, of which the fuel energy accounts for the bulk. The crude oil, petroleum products, and natural gas make up $38 \%, 24 \%$ and 14\% of total exports respectively. Although Russia takes measures and tries hard to change the situation when commodity export excessively depends on the energy, the effect is not obvious. Overall, for a long time in the future, Russia will not be able to change this situation and, hence, will be influenced by the shale energy revolution even more.

\section{Sino-Russian energy cooperation}

China and Russia have cooperated productively in the field of oil and gas resources for over twenty years. Sino-Russian energy cooperation does not only promote the countries' economic development, but also strengthens their strategic relations. However, the cooperation in field of energy suffers many setbacks.

Sino-Russian cooperation in the field of oil and gas resources could be described as "fruitful collaboration and lots of problems". In the last ten years, China and Russia have initiated many large oil and natural gas cooperation projects. In 2009, Sino-Russian petroleum companies signed a 20-year contract. Under the terms of the contract, Rosneft Oil is to export 15 million tonnes of crude oil to China through the oil pipeline in the Far East annually during 2011-2030. In 2013, Sino-Russian petroleum companies signed two petroleum contracts: one for 25 years and another for 5 years. Rosneft Oil will export 360 million tonnes of crude oil to China through the oil pipeline in the Far East within 25 years and re-export 35 million tonnes of crude oil to China within 5 years. In October 2013, Sinopec Group and Rosneft Oil signed the agreement, which specifies that Rosneft Oil is to export 10 million tonnes of crude oil to Sinopec Group every year during 2014-2023, and the sum of business transactions is predicted to reach 85 billion US dollars. Besides, in January 2017, they extended the Petroleum Purchase and Sale Agreement for another 35 million tonnes of petroleum within 5 years until the end of 2023, and the total volume increased to 91 million tonnes. In 2017, Rosneft Oil and CEFC China signed a 5-year petroleum contract. The contract specifies that CEFC China will purchase 60.8 million tonnes of petroleum from Rosneft Oil [Xu, 2016].

During the two decades of cooperation, Russia and China have not only developed the

${ }^{1}$ Zhongguo jinkou Meiguo yuanyou guimo tongbi dazeng 57 \% [China’s import of America's crude oil greatly increases by $57 \%$ on a year-on-year basis not due to the pressure from America]. Available at: http://baijiahao.baid. $\mathrm{com} / \mathrm{s}$ ? id $=1602608579421390009 \& w f r=$ spider\&for $=$ pc. $($ in Chinese $)$ 
petroleum trade from scratch, but also have changed the method of transportation from the single railway transport to the multi-channel transport with the use of railway, pipeline and marine transport. As can be seen from Figure, the countries' petroleum trade volume has increased rapidly. In 2016, China imported 52.5 million tonnes of petroleum from Russia, which accounted for $13.8 \%$ of the total petroleum imports. In 2017, China imported 59.7 million tonnes of the Russian petroleum, $13.7 \%$ more than in the year before, which accounted for $14.2 \%$ of China's total petroleum imports and $23.6 \%$ of Russia's total petroleum exports. Therefore, China became Russia's largest petroleum buyer. Since 2018, a Russia-China oil pipeline has been operating with full load, and Russia is going to export 30 million tonnes of crude oil to China through the pipeline every year [Sun, 2018].

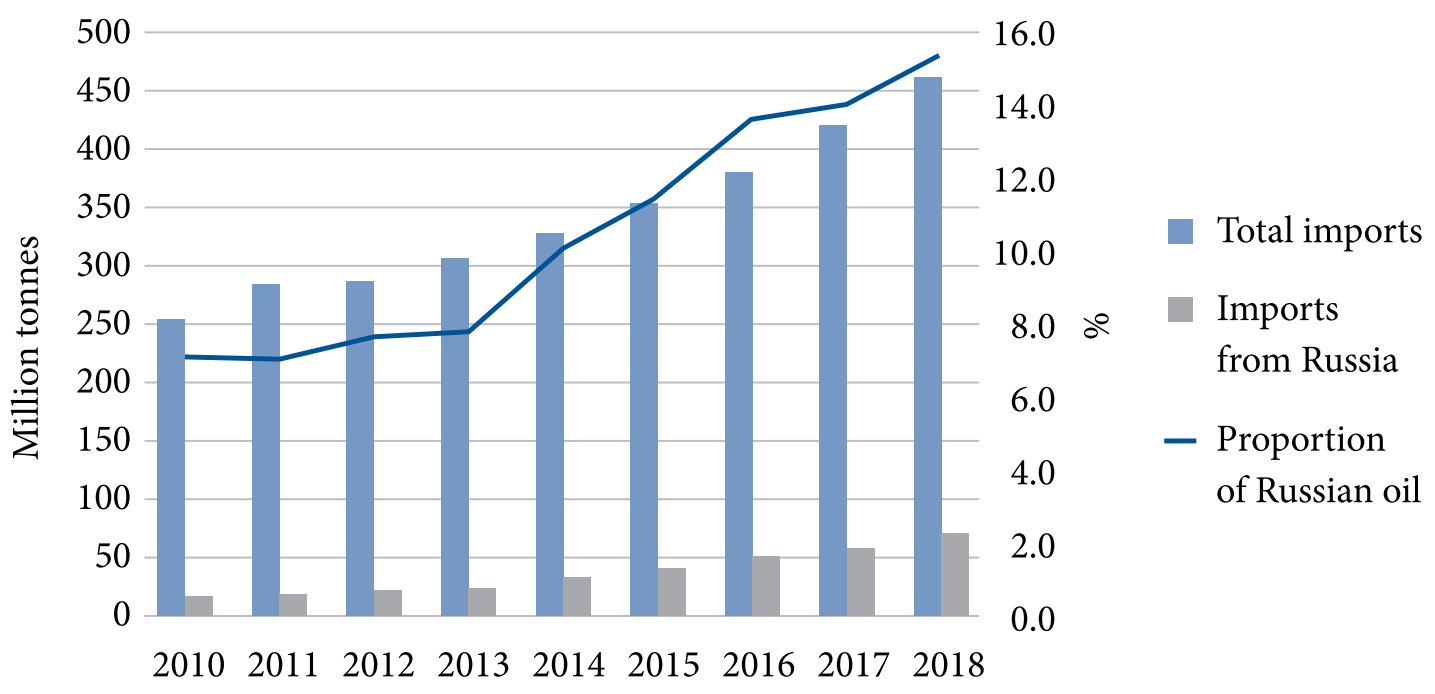

Sino-Russian oil trade in $2010-2018^{1}$

Динамика торговли нефтью между Китаем и Россией в 2010-2018 гг.

In the natural gas cooperation, China and Russia experience many problems. Although both countries have been discussing its issues for many years, only recently they have obtained certain progress. In May 2014, Gazprom and CNPC signed a gas supply agreement lasting for 30 years with the value of 400 billion US dollars. The contract specifies Russia will export 38 billion $\mathrm{m}^{3}$ of natural gas to China through the Power of Siberia gas pipeline from the end of 2019. In addition, in November 2014, CNPC and Gazprom signed the Framework Agreement on Gas Supplies via Western Route. The agreement specifies that Gazprom will export 30 billion $\mathrm{m}^{3}$ of natural gas to China annually within 30 years after the completion of the western line. If the agreement is executed, China will surpass Germany and become Russia's largest natural gas importing country.

China and Russia also achieved certain progress in joint refining of oil and gas by developing the downstream. In 2013, the agreement signed by the Government of the Russian Federation and the Government of the People's Republic of China established the cooperation in the construction and operation of the Tianjin Refinery and Petrochemical Plant. In May 2014, CNPC and Rosneft signed Work Schedule for Tianjin Refinery and Petrochemical Plant, which contains the plans to put the plant into operation before the end of 2019. In September 2013, CNPC and NOVATEK, Russia's second largest natural gas company, signed the agreement on the Yamal Cooperation Project. The project is the largest Arctic LNG project globally. According to the agreement, the CNPC purchased a $20 \%$ share in Yamal LNG project. The project aims at the annual output of 16.5 million tonnes of LNG, of which over 4 million tonnes are going to be

\footnotetext{
${ }^{1}$ Source. China General Administration of Customs. China Customs Statistics Yearbook. Beijing: China Customs Publishing Press, 2010-2018.
} 
transported to China. In November 2014, CNPC and Rosneft officially signed the cooperation framework agreement on the Vankor Oilfield project. Under the agreement, CNPC purchased a $10 \%$ share in the Vankor project. The countries also achieved a breakthrough in the upstream cooperation. In 2017, the countries agreed about a joint project, which will be implemented by the Vostok Petrochemicals joint venture ( $49 \%$ Rosneft, 51 \% CNPC). Through this venture, Rosneft Oil finally enters the PetroChina processing. The joint venture is meant to be put into operation in 2021, and the capacity is planned to reach 16 million tonnes annually, of which more than 9.1 million tonnes oil will be from Russia [Matveyev, 2018].

China has become the largest petroleum importer in the world, its petroleum import dependency approximates to $70 \%$, whereas its natural gas import dependency reaches $39.2 \%$. Based on the current consumption of oil and gas in China, its import dependency on petroleum will keep on growing, which creates an increasingly severe energy security situation for the country. As for Russia, the country is the largest energy exporter in the world, and its economy significantly depends on the export of oil and gas resources, therefore, higher energy prices and diversified energy export markets are important for maintaining the national economic security. The analysis of energy security strategies of both countries allows concluding that they have both areas of common interest and apparent contradictions. Hence, they could cooperate better only by thinking rationally, handling issues with sincerity and carefully considering the benefits.

Being the neighbours, China and Russia could strengthen their energy cooperation based on the complementarity. Strengthening the energy cooperation between the countries is of great significance for maintaining their energy security. On the one hand, Russia is a reliable supplier of the increasing amount of oil and gas resources for China. On the other hand, the oil and gas export to China meets the goals of Russia's strategy of energy export diversification and helps avoid subjection to European customers. Hence, strengthening the Sino-Russian oil and gas cooperation contributes to the energy security of both countries.

With regard to the security of the energy import channel, the Russia-to-China channel is the most secure. In addition, China could spend less in terms of transport expenses when importing energy from Siberia and the Far East areas, which allows the country to reduce the costs of importing oil and gas resources. Hence, it is of great significance to strengthen the oil and gas resources cooperation between Russia and China. Undoubtedly, the shale energy revolution does more good than harm for energy importers like China. The growth of shale oil and gas output gradually transfers the oil and gas resources from the sellers' market to the buyers' market to some extent, improves the importer's bargaining power (China) and allows Russia largely abandon the impractical economic desire. If both countries could see the shale oil and gas impact on the international energy market clearly, their energy cooperation will strengthen further.

Currently, the shale revolution is successful only in America, and is not brought about globally. Although China and Russia are the shale oil and gas reserves powers, they have not mastered the technology for mining the shale oil and gas under complicated geological conditions very well as yet. Hence, they could reduce the cost of mining the shale energy by forming an interest-based community of shale mining within two countries to jointly explore and mine the shale oil and gas resources, which would certainly make both countries cooperate more closely in the field of energy resources.

In addition, China should boost investment in capital and technology, make its shale oil and gas production technology mature as soon as possible, reduce production costs, and thus reduce the dependency on foreign oil and gas resources. Only in this case Russia will be able to grasp the reality and become enough motivated to show more initiative in oil and gas resources cooperation with China. Past experience has taught us that the greater China's dependency on Russia's energy is, the more passive the energy cooperation becomes. The major 
petroleum agreements signed by China and Russia clearly reflect the Chinese party's helplessness and the Russian party's dominance while distributing the oil transportation price between the two countries. For example, China and Russia signed an agreement on the crude oil export to China through the Far East oil pipeline. China believes that the destination of Russian oil exports to China is Skovorodino (Russia), and that China's payment of transportation costs to Russia should also be the cost of the mileage from Tayshet to Skovorodino. Russia, on the other hand, argues that its oil is exported to the countries of the Far East. Even if the Chinese party does not buy it, South Korea and Japan will buy it. The Chinese party is required to pay for the transportation in the entire Far East oil pipeline (the full mileage from Tayshet to the port of Kozmino at the coastal frontier), even if the oil to China does not pass through the section from Skovorodino to Kozmino. The Chinese party also has to pay the transportation fee, which reaches about 30 US dollars per ton. From a commercial viewpoint alone, Russia's requirements are unreasonable.

The overall picture seems to be that the Sino-Russian energy cooperation is very smooth when the situation in Russia is relatively passive, or diversification of the energy markets encounters problems. When the situation in international energy market is tense, and the oil and gas market is the seller's market, the energy cooperation between the two countries starts to suffer setbacks. Therefore, China had better to increase the shale oil and gas production. Obviously, China should not only increase the shale oil and gas exploitation, but also reduce the exploitation cost of these resources. Only by doing this China will be able to reduce the dependency on foreign oil and gas resources, strengthen its position in oil and gas cooperation with Russia, and make Russia enhance its enthusiasm and initiative in energy cooperation with China.

The enhancement of mutual political trust between China and Russia is the major power for promoting their oil and gas resources cooperation. Since the independency of Russia, the political and economic relations between China and Russia have been developing actively. Politically, both countries have established the comprehensive strategic partnership. In terms of economy and trade, China has acted as the largest trade partner of Russia for many years. Consequently, good political and economic relations of both countries are an important impetus for promoting cooperation in other fields.

\section{Conclusion}

The shale gas revolution in the USA and the global shale gas bias will accelerate the process of westward movement of global oil and gas production centers and eastward movement of consumption centers, weaken Russia's power in the international natural gas market to a certain extent, and force it to pay more attention to the Far Eastern market. Profound changes in the international energy pattern caused by the shale gas revolution may create new opportunities for the Sino-Russian energy cooperation, and accelerate the eastward shift of the Russian natural gas exports. The attractive prospects of an increase in the shale gas production in China are going to have a positive effect on the development of the Sino-Russian energy cooperation. Against the background of the shale gas revolution, for China it is advisable to keep an eye on Russia's energy strategies; build political trust; promote Sino-Russian energy cooperation at multiple levels with a particular focus on the energy prices; pay meticulous attention to the Sino-Russian energy cooperation in contiguous areas; promote the utilisation of the unconventional energy and introduction of the energy saving and emission reduction technologies. 


\section{References}

Chen X. L., Wu X. (2018). Yeyan geming beijingxiade ZhongE youqi nnengyuan hezuo [Sino-Russian oil and gas energy cooperation against the background of the shale revolution]. Xiboliya yanjiu $=$ Siberian Studies, vol. 3, pp. 45-53. Available at: http://www.cnki.net (in Chinese)

Matveyev B. A. (2018). Shijie nengyuan shichang fazhan qushi he Zhong E nengyuan hezuo [Development tendencies of world energy market and Sino - Russian energy cooperation]. Ouya jingji yanjiu = Russian, East European \& Central Asian Studies, vol. 3, pp. 96-99. Available at: http://www.cnki.net (in Chinese, transl. by Nong Xuemei)

Men X. X., Han Z. H., Wang L. (2018). Yeyanqi ziyuan kantan kaifa lishi ji xianzhuang [History and current situation of exploration and development of shale gas resources]. Xinjiang shiyou dizhi=Xinjiang Petroleum Geology, vol. 6, pp. 372-376. Available at: http://www.cnki.net (in Chinese)

O'Sullivan M. L. (2017). Windfall: How the new energy abundance upends global politics and strengthens America’s power. N.Y.: Simon \& Schuster. 496 p.

Sun Y. X. (2018). Eluosi zai guoji nengyuan geju zhong rengshi qiangguo diwei [Russia is still in great power status in international energy layout]. Ouya jingji yanjiu = Russian, East European \& Central Asian Studies, vol. 3, pp. 72-76. Available at: http://www.cnki.net (in Chinese)

Wang E. D., Jin Z. J. (2018). Zhongguo yichengei shijie disanda yeyanqi shengchanguo dan yeyanyou geming yuanwei daolai [China has become the third largest shale gas production country in the world, but the shale oil revolution has not come yet]. 21 shiji jingji baodao $=21^{\text {st }}$ Century Business Herald. Available at: http://www.cnki.net (in Chinese)

Wang Y. (2018). Genfeng meiguo yeyanqi de shifei [Right and wrong aspects of following the trend of America’s shale gas]. Nengyuan = Energy, vol. 3, pp. 52-55. Available at: http://www.cnki.net (in Chinese)

$\mathrm{Xu}$ H. F. (2016). Pujing disan renqi yilai Zhong E nengyuan hezuo xinjinzhan ji qianzai zhangai [New progress and potential barriers of Sino - Russian energy cooperation since the third tenure of Putin]. Eluosi zhongya dongou yanjiu = Russian, East European \& Central Asian Studies, vol. 6, pp. 60-65. Available at: http://www.cnki.net (in Chinese)

Yin J. P., Zhang J. (2013). Meiguo nengyuan duiwai yichundu de bianhua jiqi qishi [Change and enlightenment of import dependency of America's energy]. Dui wai maoyi wush = Foreign Economic Relations and Trade, vol. 7, pp. 23-25. Available at: http://www.cnki.net (in Chinese)

\section{Information about the author}

Anquan Feng, PhD (Economics), Assistant Prof. of Applied Economics Dept., Heilongjiang Academy of Social Sciences, 1000 Shibo Road, Songbei District, Harbin, 150028, China

Phone: +86-136-4431-3861, e-mail: anquanf@hotmail.com 


\title{
Сотрудничество России и Китая в условиях сланцевой революции
}

\begin{abstract}
Аннотация. По мере технического прогресса стоимость производства сланцевых нефтегазовых ресурсов снижается, что увеличивает их конкурентоспособность. Данный факт изменит структуру международного рынка нефтегазового сырья. Представленное исследование посвящено анализу влияния сланцевой революции на международный энергетический рынок и выявлению тенденций энергетического сотрудничества Китая и России. Методологической базой исследования послужила концепция пространственного смещения центров добычи и потребления нефтегазовых ресурсов. Основной метод исследования - сравнительный анализ динамики экспорта и импорта энергетических ресурсов Китая и России в условиях развертывания сланцевых технологий. Влияние сланцевой революции на Китай отразилось в увеличении числа каналов импорта нефти и газа, росте показателей объема добычи нефти и газа, сокращении импорта энергии и усилении роли страны на международных энергетических рынках. Влияние на Россию заключается в повышении конкурентного давления на энергетических рынках и росте стимулов к использованию нетрадиционных источников энергии в стране. Результатом исследования является определение перспектив российско-китайского сотрудничества в сфере экспорта и импорта нефти и газа с учетом формирующейся структуры рынков, а также препятствий к успешному взаимодействию.
\end{abstract}

Ключевые слова: сланцевая революция; Россия; Китай; нефть; газ; энергетическое сотрудничество.

Для иитирования: Feng A. Q. Shale revolution and Sino-Russian energy cooperation // Journal of New Economy. 2019. T. 20, № 4. C. 108-118. DOI: 10.29141/2073-1019-2019-20-4-6

Дата поступления: 29 апреля 2019 г.

\section{Источники}

Chen X. L., Wu X. (2018). Yeyan geming beijingxiade ZhongE youqi nnengyuan hezuo [Sino-Russian oil and gas energy cooperation against the background of the shale revolution]. Xiboliya yanjiu $=$ Siberian Studies, vol. 3, pp. 45-53. Available at: http://www.cnki.net (in Chinese)

Matveyev B. A. (2018). Shijie nengyuan shichang fazhan qushi he Zhong E nengyuan hezuo [Development tendencies of world energy market and Sino - Russian energy cooperation]. Ouya jingji yanjiu = Russian, East European \& Central Asian Studies, vol. 3, pp. 96-99. Available at: http://www.cnki.net (in Chinese, transl. by Nong Xuemei)

Men X. X., Han Z. H., Wang L. (2018). Yeyanqi ziyuan kantan kaifa lishi ji xianzhuang [History and current situation of exploration and development of shale gas resources]. Xinjiang shiyou dizhi=Xinjiang Petroleum Geology, vol. 6, pp. 372-376. Available at: http://www.cnki.net (in Chinese)

O'Sullivan M. L. (2017). Windfall: How the new energy abundance upends global politics and strengthens America's power. N.Y.: Simon \& Schuster. 496 p.

Sun Y. X. (2018). Eluosi zai guoji nengyuan geju zhong rengshi qiangguo diwei [Russia is still in great power status in international energy layout]. Ouya jingji yanjiu = Russian, East European \& Central Asian Studies, vol. 3, pp. 72-76. Available at: http://www.cnki.net (in Chinese)

Wang E. D., Jin Z. J. (2018). Zhongguo yichengei shijie disanda yeyanqi shengchanguo dan yeyanyou 
geming yuanwei daolai [China has become the third largest shale gas production country in the world, but the shale oil revolution has not come yet]. 21 shiji jingji baodao $=21^{\text {st }}$ Century Business Herald. Available at: http://www.cnki.net (in Chinese).

Wang Y. (2018). Genfeng meiguo yeyanqi de shifei [Right and wrong aspects of following the trend of America's shale gas]. Nengyuan = Energy, vol. 3, pp. 52-55. Available at: http://www.cnki.net (in Chinese)

$\mathrm{Xu}$ H. F. (2016). Pujing disan renqi yilai Zhong E nengyuan hezuo xinjinzhan ji qianzai zhangai [New progress and potential barriers of Sino-Russian energy cooperation since the third tenure of Putin]. Eluosi zhongya dongou yanjiu = Russian, East European \& Central Asian Studies, vol. 6, pp. 60-65. Available at: http://www.cnki.net (in Chinese)

Yin J.P ., Zhang J. (2013). Meiguo nengyuan duiwai yichundu de bianhua jiqi qishi [Change and enlightenment of import dependency of America's energy]. Dui wai maoyi wush = Foreign Economic Relations and Trade, vol. 7, pp. 23-25. Available at: http://www.cnki.net (in Chinese)

\section{Информация об авторе}

Фэн Аньцюань, $\mathrm{PhD}$ (Economics), доцент кафедры прикладной экономики Академии общественных наук провинции Хэйлунцзян, 150028, КНР, Харбин, р-н Сун Бэй, ул. Шибо, 1000 Контактный телефон: +86-136-4431-3861, e-mail: anquanf@hotmail.com

(C) Feng A. Q., 2019 